\title{
Urinary Oxalate Excretion Decreased in Androgen Receptor-Knockout Mice by Suppressing Oxalate Synthesis in the Liver
}

\author{
Sayuri Takahashi ${ }^{1}$, Seiji Aruga ${ }^{1,2^{*}}$, Yoko Yamamoto ${ }^{3}$, Takahiro Matsumoto ${ }^{4}$, \\ Tadaichi Kitamura1, Yukio Homma ${ }^{1}$ \\ ${ }^{1}$ Department of Urology, the University of Tokyo, Tokyo, Japan \\ ${ }^{2}$ Department of Urology, Kyosai Hospital, Tokyo, Japan \\ ${ }^{3}$ Department of Surgical Oncology, the University of Tokyo, Tokyo, Japan \\ ${ }^{4}$ Institute of Health Biosciences, the University of Tokushima Graduate School, Tokushima, Japan \\ Email: *aruga-tky@umin.ac.jp
}

Received 17 July 2015; accepted 16 August 2015; published 19 August 2015

Copyright (C) 2015 by authors and Scientific Research Publishing Inc.

This work is licensed under the Creative Commons Attribution International License (CC BY). http://creativecommons.org/licenses/by/4.0/

(c) (7) Open Access

\section{Abstract}

The incidence of calcium oxalate stone in men is higher than that in women. We evaluated the association between the androgen receptor (AR) and urinary oxalate excretion using Cre-floxed male androgen receptor-knockout (ARKO) mice $\left(\mathrm{AR}^{\mathrm{L}-} / \mathrm{Y}\right)$ and floxed mice $\left(\mathrm{AR}^{\mathrm{L}+} / \mathrm{Y}\right)$ as control. Fourteen-week-old $A R^{L-/ Y}$ and $A R^{L+/ Y}$ mice were fed distilled water. Drinking water was then swapped for $0.5 \%$ ethylene glycol (EG). Urinary oxalate was measured on days 0,14 , and 28 . Urinary calcium, inorganic phosphorus, citrate, uric acid, and ion-actibity products of calcium oxalate (AP$\mathrm{CaOx}$ ) in mouse, AP (CaOx)-index ${ }_{\mathrm{MOUSE}}$, were evaluated on days 0 and 15 . On day 28, livers were harvested to measure mRNA expression of enzymes. Urinary oxalate excretion was significantly higher in $\mathrm{AR}^{\mathrm{L}+/ \mathrm{Y}}$ than in $\mathrm{AR}^{\mathrm{L}-/ \mathrm{Y}}$ mice 14 and 28 days after $\mathrm{EG}$ treatment $(p<0.05)$. Since $\mathrm{AR}^{\mathrm{L}-/ \mathrm{Y}}$ mice exhibited atrophic testes and low serum testosterone, both ARKO and control mice were orchiectomized and implanted DHT pellets (AR ${ }^{\mathrm{L}-/ \mathrm{Y}-O R X-D H T}$, and $A R^{\mathrm{L}+/ \mathrm{Y}-O R X-D H T}$ ), and the same experiments as above were performed. EG loading for 14 and 28 days resulted in significantly higher excretion in $\mathrm{AR}^{\mathrm{L}+} / \mathrm{Y}-\mathrm{ORX}$-DHT mice than $\mathrm{AR}^{\mathrm{L}-} / \mathrm{Y}-\mathrm{ORX}$-DHT mice $(p<0.005)$. AP(CaOx)-index ${ }_{\mathrm{MOusE}}$ was significantly higher in $\mathrm{AR}^{\mathrm{L}+} / \mathrm{Y}_{-} \mathrm{ORX}-\mathrm{DHT}$ mice than in $\mathrm{AR}^{\mathrm{L}-} / \mathrm{Y}_{-} \mathrm{ORX}-\mathrm{DHT}$ mice. mRNA expression levels of glycolate oxidase (GO) in liver were lower in ARKO mice than in control ones. AR modulates the excretion of oxalate in urine after EG treatment, which may be associated with increased oxalate synthesis by activated GO in the liver via the AR pathway.

${ }^{*}$ Corresponding author.

How to cite this paper: Takahashi, S., Aruga, S., Yamamoto, Y., Matsumoto, T., Kitamura, T. and Homma, Y. (2015) Urinary Oxalate Excretion Decreased in Androgen Receptor-Knockout Mice by Suppressing Oxalate Synthesis in the Liver. Open Journal of Urology, 5, 123-132. http://dx.doi.org/10.4236/oju.2015.58020 
Keywords

Androgen Receptor, Urinary Stone, Oxalate

\section{Introduction}

The incidence of idiopathic calcium oxalate $(\mathrm{CaOx})$ renal stone disease in men is 2.5 - 3 times higher than that in women [1] [2]. Although the reason for the gender disparity remains unclear, the several studies have demonstrated that urinary excretion of calcium, oxalate, and uric acid is higher, and that of citrate is lower, in males than in females [3] [4]. Among these substances, urinary oxalate is a strong dicarboxylic organic acid that forms insoluble salt with calcium, and is one of the most important factors in calcium oxalate kidney stone formation [5] [6]. The sources of urinary oxalate are considered to be hepatic synthesis and the diet. In humans, the absorption of dietary oxalate constitutes $30 \%-50 \%$ of urinary oxalate excretion [7] [8], and hepatic synthesis is thus considered important. In the liver, oxalate is produced from glycolate via glyoxylate in the hepatic peroxysomes, and this oxidation is catalyzed by glycolate oxidase (GO), lactate dehydrogenase and xanthine oxidase [9]-[11]. Meanwhile, glyoxylate is metabolized to glycine by serine pyruvate aminotransferase/alanine: glyoxylate amino transferase (SPT/AGT), which is thought to inhibit oxalate synthesis [12].

Several experimental studies have been conducted to explain gender differences in the prevalence of urolithiasis [13]-[19]. Lee et al. demonstrated that urolithiasis was generated in intact male rats, but not female rats, after being fed ethylene glycol (EG), the precursor of oxalate [13]. They also demonstrated that the castrated male rats fed EG dramatically decreased the incidence of renal stones. In addition, they evaluated the contribution of sex hormones in urolithiasis by subcutaneously implanting testosterone into intact and castrated male and oophorectomized female rats, and found that exogenous testosterone could restore kidney stone forming tendency in EG-fed castrated rats and enhance stone formation in oophorectomized female rats [14]. Furthermore, Yoshihara et al. showed that increased urinary oxalate excretion is associated with testosterone-promoted enhanced GO activity [15]. On the other hand, estrogen inhibits urinary oxalate excretion [16]-[19]. These studies suggested that androgens are associated with renal $\mathrm{CaOx}$ stone formation by increasing urinary oxalate excretion through hepatic synthesis. Androgens are essential for the differentiation and growth of male reproductive organs as well as for various biological effects in the kidney, brain, liver, muscle, bone, and skin. In males, testosterone is the major circulating androgen, and $95 \%$ of it is bound by sex hormone-binding protein [20]. The most biologically active form of endogenous androgens is $5 \alpha$-dihydrotestosterone ( $5 \alpha$-DHT), which is converted from its precursor, testosterone, by the action of a P450 family member enzyme, 3-oxo-5 $\alpha$-steroid 4-dehydrogenase, commonly known as $5 \alpha$-reductase [21]. Testosterone is approximately 100 -fold less biologically active than $5 \alpha$-DHT [21]. Free testosterone (1\% - 2\% of total testosterone) diffuses into target cells, is converted to $5 \alpha$-DHT and binds to androgen recdeptor (AR), a nuclear receptor, which regulates androgen signaling [22]. Although the androgens are play an important role in renal $\mathrm{CaOx}$ stone formation, the role of $\mathrm{AR}$ in oxalate metabolism has not been well studied.

In the present study, we used the androgen receptor (AR) - knockout (KO) mice generated by means of Cre-loxP system [23]. To assess how AR is related to oxalate metabolisms, we evaluated urinary oxalate levels and the expression of hepatic GO and AGT mRNA during EG loading in ARKO mice. In addition, we also assessed the urinary excretion of other kidney stone-related substances, including calcium, inorganic phosphorus, citrate, and uric acid, and calculated the ion-actibity products of calcium oxalate (APCaOx) in mouse, $\mathrm{AP}(\mathrm{CaOx})$ index $_{\text {MOUSE }}$ index, to evaluate the risk of in vivo crystallization of urinary calcium oxalate in both control mice and ARKO mice.

\section{Materials and Methods}

\subsection{Generating ARKO Mice}

The genomic AR DNA fragment was isolated from a TT2 embryonic stem (ES) cell genomic library using human AR A/B domain cDNA as a probe. The targeting vector consisted of a 7.6-kb $5^{\prime}$ region containing exon-1, a 1.3-kb 3' homologous region, a single loxP site, and a neo cassette with two loxP sites [24]. Targeted clones 
(FB-18 and FC-61) were aggregated with single eight-cell embryos from CD-1 mice to generate chimeras, as described previously [23] [25], and floxed AR mice (C57BL/6) were obtained. The floxed AR mice were then crossed with CMV-Cre transgenic mice provided by Pierre Chambon et al. [26]. The chromosomal sex of each pup was determined by genomic polymerase chain reaction (PCR) analysis of the Y chromosome Sry gene, which is expressed in male urogenital ridge at a time consistent with its having a role in testis determination [27]. The genotype of animals was then confirmed by Southern blotting. We mated male $\mathrm{AR}^{\mathrm{L}+/ \mathrm{Y}}$ mouse with female CMV-Cre-AR ${ }^{\mathrm{L}-/+}$ mouse. We gained $\mathrm{AR}^{+/ \mathrm{Y}}$, CMV-Cre $\mathrm{AR}^{+/ \mathrm{Y}}, \mathrm{AR}^{\mathrm{L}-/ \mathrm{Y}}, \mathrm{CMV}-\mathrm{Cre} \mathrm{AR}^{\mathrm{L}-/ \mathrm{Y}}, \mathrm{AR}^{\mathrm{L}-/ \mathrm{L}^{+}}$, CMV-Cre $\mathrm{AR}^{\mathrm{L}-/ \mathrm{L}^{-}}, \mathrm{AR}^{\mathrm{L}+/+}$, and CMV-Cre $\mathrm{AR}^{\mathrm{L}^{-/+}}$[28]. $\mathrm{AR}^{\mathrm{L}-/ \mathrm{Y}}$ mice are infertile; therefore, we mated $\mathrm{AR}^{\mathrm{L}+/ \mathrm{Y}}$ mouse with $\mathrm{AR}^{\mathrm{L}-/ \mathrm{L}^{+}}$mouse and gained $\mathrm{AR}^{\mathrm{L}-/ \mathrm{Y}}$ and $\mathrm{AR}^{\mathrm{L}+/ \mathrm{Y}}$ mice. $\mathrm{AR}^{\mathrm{L}-/ \mathrm{Y}}$ mice were used as ARKO mice, and male floxed AR mice $\left(A R^{L+/ Y}\right)$ breeding pairs of the same genetic background were used as controls.

\subsection{Animal Groups, Treatment and Urine Collection}

All mice were fed a standard commercial diet (Rodent Diet CE-2; CLEA Japan, Tokyo, Japan) and given distilled water. At 14 weeks of age, five $\mathrm{AR}^{\mathrm{L}-\mathrm{Y}}$ and five $\mathrm{AR}^{\mathrm{L}+/ \mathrm{Y}}$ mice were weighed, and administered $0.5 \%$ ethylene glycol (EG) as drinking water for 28 days because glycolic acid oxidase is involoved in the metabolism of ethylene glycol to oxlate, and the activity may be enhanced by testosterone [16]. Using a metabolic cage, 24-h urine samples were collected from each mouse at three time points: before the administration of EG, after 14 days of treatment, and after 28 days of treatment. Urine samples were acidified with concentrated $\mathrm{HCl}$ to a $\mathrm{pH}<$ 3.0 for measurement of urinary oxalate. Next, groups of five $A^{L+/ Y}$ and $A R^{L-/ Y}$ mice underwent orchiectomy (ORX) or sham operation, and were then subcutaneously implanted with 60-day sustained release dihydrotestosterone (DHT) pellets (10 mg; Innovative Research). These orchiectomized DHT-implanted $\mathrm{AR}^{\mathrm{L}+/ \mathrm{Y}}$ mice $\left(\mathrm{AR}^{\mathrm{L}+/ \mathrm{Y}}-\mathrm{ORX}-\mathrm{DHT}\right)$, and orchiectomized DHT-implanted $\mathrm{AR}^{\mathrm{L}-/ \mathrm{Y}}$ mice $\left(\mathrm{AR}^{\mathrm{L}-\mathrm{Y}}-\mathrm{ORX}-\mathrm{DHT}\right)$ were given a normal diet and distilled water for 7 days. The distilled water was then replaced with 0.5\% EG for 28 days. Afterward, 24-h urine samples were collected and acidified with concentrated $\mathrm{HCl}$ at three points; before the administration of EG, after 14 days of treatment, and after 28 days of treatment.

\subsection{Blood Collection, Removal of Kidney and Liver, Determination of Uriary Chemistry, Serum Testosterone and Luteinizing Hormone (LH)}

Urinary oxalate levels were determined at all points using high-performance liquid chromatography (HPLC) [29]. Urinary citrate levels were also measured by HPLC before EG treatment and after 15 days of treatment. Urinary calcium, uric acid, and inorganic phosphorus levels were measured before EG treatment and 14 days after by the o-cresolphthalein complexone method [30], uricase-POD method, and molybdic acid method, respectively. To evaluate the risk of in vitro crystallization of calcium oxalate in urine, AP(CaOx)-index ${ }_{\text {MOUSE }}$ index was then calculated on the basis of the urinary data obtained before and after 15 days of EG treatment, using the formula described by Tiselius et al. [31];

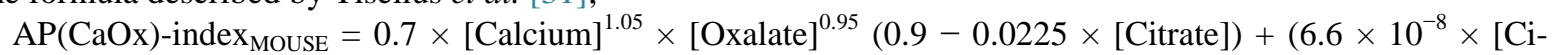
trate $\left.]^{3.98}\right)$, where [Calcium], [Oxalate], and [Citrate] are the measured urinary levels (mmol/L).

Mice were sacrificed after 28 days of EG treatment. Immediately after blood samples were obtained, both the kidneys and the liver were removed. The serum levels of testosterone and luteinizing hormone (LH) in $A R^{L-/ Y}$ and $\mathrm{AR}^{\mathrm{L}+\mathrm{Y}}$ mice were measured by electrochemiluminescent immunoassay by using Eclusys testosterone kit ${ }^{\circledR}$ and Architect LH kit ${ }^{\circledR}$ respectively. Serum creatinine concentration levels were determined using the alkalinel picrate method (SRL Ltd., Tokyo, Japan). One side of kidneys was cut longitudinally, fixed in 4\% paraformaldehyde, and embedded in paraffin. For the observation of renal morphology, crystals or stones in renal pelvis, the paraffin-embedded kidneys were cut into 8- $\mu \mathrm{m}$ sections, stained with hematoxylin and eosin, and mounted on slides. The other kidney was used to assess calcium content. Briefly, the kidneys were minced in a beaker, and then $2 \mathrm{ml}$ of $0.5-\mathrm{N}$ nitric acid was added. The beaker was then heated until the liquid become transparent, and up to $5 \mathrm{ml}$ of distilled water was added to the solvent extract, with stirring. After calibration using a standard calcium solution, the calcium content was determined by atomic absorption spectroscopy [32]. For measuring the mRNA expression of GO and AGT, the livers were placed under liquid nitrogen, and were stored at $-70^{\circ} \mathrm{C}$ until analysis.

All studies were conducted in an accredited animal care facility, and all protocols were approved by the Ethics Committee of the University of Tokyo, which is in accordance with the National Institute of Health guide- 
lines for the care and use of laboratory animals. Carbon dioxide inhalation was used for the euthanasia of the mice.

\subsection{Northern Blot Analysis}

Frozen liver samples were homogenized in ISOGEN (Nippon gene, Japan), and total RNA was extracted following the manufacturer's instructions. Oligo-dT-primed cDNA was synthesized from $1 \mu \mathrm{g}$ of liver RNA from a wild-type male mouse (C57BL/6) using SuperScript reverse transcriptase (Gibco BRL, Gaithersburg, MD) in a $20-\mu l$ reaction volume. The cDNA probe templates were PCR-amplified from the cDNA. Primers were designed from cDNA sequences of mouse GAPDH, GO, and AGT using the primer pairs 5'-ACCACAGTCCATGCCAT CAC-3' and 5'-TCCACCACCCTGTTGCTGTA-3' (437 bp), 5'-ATGTTGCCTCCGACTGGTCTG-3' and 5'-TC AFATCTTGGAAACAGCCAAAGG-3' (1113 bp), and 5'-AACCFFTATTGCTGTTCCTG-3' and 5'-CTCCAG CACATAGCTGACGA-3' (581 bp), respectively. The annealing temperatures were 60, 58, and 57 degrees Celsius, respectively. Digoxigenin (DIG)-labeled probes were created using a DIG DNA Labeling Mix (Roche Diagnostic K.K., Japan). Extracted total RNA was transferred onto nitrocellulose membranes, and membranes were pre-hybridized with DIG easy Hyb solution at $50^{\circ} \mathrm{C}$. Membranes were then hybridized overnight with each DIG labeled probe at $50^{\circ} \mathrm{C}$, washed, blocked using the DIG Wash and Block Buffer Set, incubated with Anti-DIG-AP, Fab fragments (Roche Diagnostic K.K), and detected using CDP-Star Reagent (New England Biolabs). RNA bands were quantified using the IMAGEJ software package and normalized by GAPDH [33] [34].

\subsection{Statistical Analyses}

Statistical analysis was performed using unpaired Student's $t$ tests to evaluate the differences in serum LH, testosterone and urinary levels of substances between control and ARKO mice, one-way repeated measurement analysis of variance (ANOVA) to evaluate the effect of the ethylene glycol treatment within each group using the JMP computer statistical software. All values are expressed as mean \pm standard errors.

\section{Results}

\subsection{Renal Morphology and Function of ARKO Male Mice}

$A R^{L-/ Y}$ mice exhibited a female-typical external appearance. We confirmed that atrophic testes in 14-week-old $\mathrm{AR}^{\mathrm{L}-/ \mathrm{Y}}$ resulted in lower levels of testosterone ( $p=0.052$, statistically marginal significant) and higher levels of LH ( $p=0.046)$ (Figure 1(a) and Figure 1(b)), as previously described for seven to twenty-week-old mice [35]. There were no significant differences between body weight, 24-h fluid intake, and urine $\mathrm{pH}$ between $\mathrm{AR}^{\mathrm{L}-/ \mathrm{Y}}$ and $\mathrm{AR}^{\mathrm{L}+/ \mathrm{Y}}$ at 14 week of age (Table 1). Kidneys and livers appeared normal macroscopically (data not shown). Histological analysis revealed no significant abnormality in the glomeruli, proximal tubules and collecting ducts (Figure 1(c)). In addition, the 24-h urine volume and the serum creatinine levels after 14 days of EG treatment was comparable between $A R^{\mathrm{L}-/ Y}$ and $A R^{\mathrm{L}+/ Y}$ (Table 1). This suggests that the kidney function of the $A R^{\mathrm{L}-/ Y}$ mice was in the normal range. As shown in Table 1, amount of urinary excretion of calcium, uric acid, inorganic phosphorus and citrate in $\mathrm{AR}^{\mathrm{L}-/ \mathrm{Y}}$ mice also did not differ from $\mathrm{AR}^{\mathrm{L}+/ \mathrm{Y}}$ mice, either before treatment or after 15 days of treatment.

\subsection{Urinary Oxalate Excretion Was Suppressed in ARKO Mice}

The 24-h urinary excretion of oxalate in $\mathrm{AR}^{\mathrm{L}-/ \mathrm{Y}}$ mice was less than that in $\mathrm{AR}^{\mathrm{L}+\mathrm{Y}}$ mice, but the difference was not statistically significant ( $p=0.09$, unpaired t-test) (Table 2). After treatment with EG for 14 days and 28 days, the excretion of oxalate was increased between 2.5 and 4.8 times in both $\mathrm{AR}^{\mathrm{L}-/ \mathrm{Y}}$ and $\mathrm{AR}^{\mathrm{L}+/ \mathrm{Y}}(p<0.001$, one way ANOVA) (Table 2). The amount of urinary oxalate excreted by $\mathrm{AR}^{\mathrm{L}+/ \mathrm{Y}}$ was significantly higher than urinary oxalate excreted by $\mathrm{AR}^{\mathrm{L}-/ \mathrm{Y}}(p<0.05$ at 14 days and 28 days unpaired t-test) (Table 2).

\subsection{Urinary Oxalate Excretion Was Suppressed in ARKO Mice by ORX and DHT}

Serum testosterone concentrations were decreased due to atrophic testes in $\mathrm{AR}^{\mathrm{L}-/ \mathrm{Y}}$ mice. To address this issue, we orchiectomized $\mathrm{AR}^{\mathrm{L}+/ \mathrm{Y}}$ or sham operated $\mathrm{AR}^{\mathrm{L}-/ \mathrm{Y}}$ mice, and then implanted DHT pellets subcutaneously. In mice fed a normal diet and distilled water, the level of urinary oxalate was 1.7 times higher in $\mathrm{AR}^{\mathrm{L}+/ \mathrm{Y}}-\mathrm{ORX}-\mathrm{DHT}$ mice than that in $\mathrm{AR}^{\mathrm{L}-/ \mathrm{Y}}$-ORX-DHT mice but the difference was not statistically significant $(p=0.209$, unpaired 
(a)

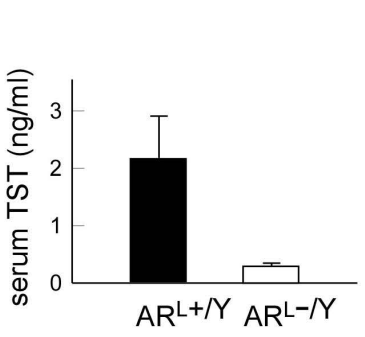

(b)

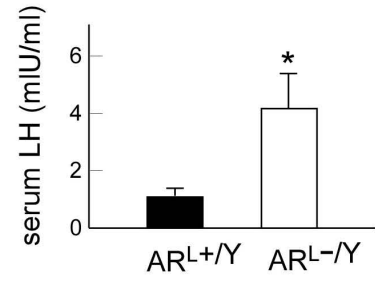

(c)
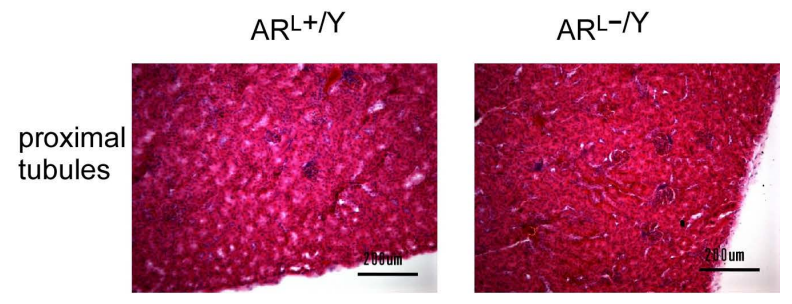

collect ducts
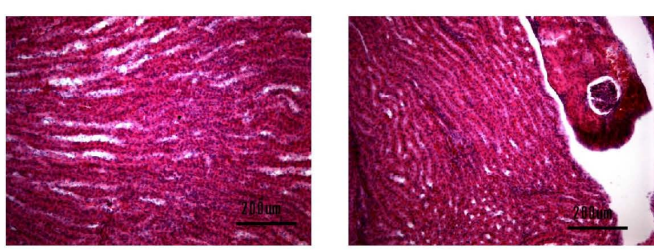

Figure 1. (a) Serum testosterone levels in the $A R^{L+/ Y}$ mice and $A R^{L-/ Y}$ mice; $n=5$. Testosterone level was 8.58 times higher in the $\mathrm{AR}^{\mathrm{L}+/ \mathrm{Y}}$ mice; however, the difference was not statistically significant; (b) Serum luteinizing hormone levels in the $\mathrm{AR}^{\mathrm{L}+/ \mathrm{Y}}$ mice and $\mathrm{AR}^{\mathrm{L}-/ \mathrm{Y}}$ mice; $\mathrm{n}=5$. Luteinizing hormone level was significantly higher in the $\mathrm{AR}^{\mathrm{L}-/ \mathrm{Y}}$ mice $\left(^{*}, p<0.05\right)$; $(\mathrm{c})$ Representative microscopic photographs of hematoxylin and eosin stained proximal tubules or collecting ducts of the $\mathrm{AR}^{\mathrm{L}+Y}$ mice and $A R^{\mathrm{L}-/ \mathrm{Y}}$ mice. Pathologically, there were no remarkable differences between the $A R^{\mathrm{L}+/ \mathrm{Y}}$ mice and $A R^{\mathrm{L}-/ \mathrm{Y}}$ mice.

Table 1. Body weight, urinary $\mathrm{pH}$, serum and urinary chemistry of mice.

\begin{tabular}{|c|c|c|c|c|c|c|}
\hline & $\begin{array}{l}\mathrm{AR}^{+/ \mathrm{Y}} \\
\text { intact }\end{array}$ & $\begin{array}{l}\mathrm{AR}^{\mathrm{L}-/ \mathrm{Y}} \\
\text { intact }\end{array}$ & $p$ value ${ }^{*}$ & $\begin{array}{c}\mathrm{AR}^{+/ \mathrm{Y}} \\
\mathrm{ORX}+\mathrm{DHT}\end{array}$ & $\begin{array}{c}\mathrm{AR}^{\mathrm{L}-/ Y} \\
\mathrm{ORX}+\mathrm{DHT}\end{array}$ & $p$ value ${ }^{*}$ \\
\hline Body weight & $35.66 \pm 2.55$ & $39.30 \pm 3.49$ & 0.45 & $39.12 \pm 2.81$ & $39.78 \pm 2.54$ & 0.88 \\
\hline Fluid intake & $6.26 \pm 0.19$ & $5.89 \pm 0.94$ & 0.60 & $5.28 \pm 0.24$ & $5.64 \pm 0.27$ & 0.51 \\
\hline Urine $\mathrm{pH}$ & $7.60 \pm 0.19$ & $7.50 \pm 0.22$ & 0.74 & $7.50 \pm 0.16$ & $7.60 \pm 0.19$ & 0.69 \\
\hline \multicolumn{7}{|l|}{ Before EG treatment } \\
\hline Urinary volume & $1.49 \pm 0.32$ & $1.15 \pm 0.27$ & 0.23 & $1.34 \pm 0.24$ & $1.34 \pm 0.38$ & 0.55 \\
\hline Urinary calcium & $0.80 \pm 0.11$ & $0.68 \pm 0.13$ & 0.52 & $0.41 \pm 0.10$ & $0.68 \pm 0.18$ & 0.23 \\
\hline Urinary inorganic phosphorus & $34.14 \pm 7.84$ & $22.67 \pm 3.84$ & 0.24 & $24.75 \pm 6.67$ & $23.75 \pm 5.15$ & 0.91 \\
\hline Urinary uric acid & $0.16 \pm 0.03$ & $0.12 \pm 0.03$ & 0.30 & $0.25 \pm 0.07$ & $0.19 \pm 0.03$ & 0.42 \\
\hline Urinary citrate & $2.06 \pm 0.62$ & $1.26 \pm 0.32$ & 0.29 & $1.32 \pm 0.33$ & $1.46 \pm 0.50$ & 0.82 \\
\hline APCaOx index & $0.67 \pm 0.11$ & $0.75 \pm 0.19$ & 0.34 & $0.56 \pm 0.28$ & $0.67 \pm 0.13$ & 0.38 \\
\hline Urinary creatinine & $3.52 \pm 0.50$ & $3.66 \pm 0.51$ & 0.85 & $5.10 \pm 0.11$ & $3.92 \pm 0.60$ & 0.38 \\
\hline \multicolumn{7}{|l|}{ After EG treatment } \\
\hline Urinary volume & $2.23 \pm 0.53$ & $2.02 \pm 0.47$ & 0.39 & $1.16 \pm 0.17$ & $0.66 \pm 0.35$ & 0.12 \\
\hline Urinary calcium & $1.13 \pm 0.16$ & $1.12 \pm 0.26$ & 0.95 & $0.63 \pm 0.10$ & $0.67 \pm 0.39$ & 0.92 \\
\hline Urinary inorganic phosphorus & $47.15 \pm 11.86$ & $34.31 \pm 0.08$ & 0.39 & $24.59 \pm 2.99$ & $25.59 \pm 2.99$ & 0.96 \\
\hline Urinary uric acid & $0.19 \pm 0.03$ & $0.17 \pm 0.05$ & 0.79 & $0.06 \pm 0.01$ & $0.08 \pm 0.04$ & 0.52 \\
\hline Urinary citrate & $3.04 \pm 0.56$ & $2.39 \pm 0.75$ & 0.94 & $1.53 \pm 0.36$ & $0.91 \pm 0.54$ & 0.37 \\
\hline APCaOx index & $2.94 \pm 0.64$ & $1.61 \pm 0.20$ & $<0.05$ & $3.75 \pm 0.83$ & $1.79 \pm 0.63$ & $<0.05$ \\
\hline Serum creatinine & $5.66 \pm 0.60$ & $7.07 \pm 0.63$ & 0.71 & $7.25 \pm 0.98$ & $7.43 \pm 1.21$ & 0.46 \\
\hline Urinary creatinine & $3.26 \pm 0.26$ & $4.77 \pm 0.57$ & 0.054 & $1.42 \pm 0.66$ & $2.72 \pm 0.39$ & 0.64 \\
\hline
\end{tabular}

Unit of Body Weight: g.

Unit of Serum: $10^{-6} \mathrm{~mol} / \mathrm{L}$, Urinary Creatinine: $10^{-3} \mathrm{~mol} / \mathrm{L}$.

Unit of Urinary Volume and Fluid Intake: $\mathrm{ml} / 24$ hour.

Units of Urinary Calcium, Inorganic Phosphorus, Uric Acid and Citrate: $10^{-4} \mathrm{~mol} / 24 \mathrm{hour} / \mathrm{kg}$. ${ }^{*}$ T-test. 
t-test) (Table 2). After 14 days and 28 days of EG treatment, the urinary excretion of oxalate was increased within each group $\left(p<0.001\right.$, one way ANOVA). $\mathrm{AR}^{\mathrm{L}+/ \mathrm{Y}}$-ORX-DHT mice excreted oxalate 3.9 times more than $\mathrm{AR}^{\mathrm{L}-\mathrm{Y}}$ ORX-DHT mice after 14 days of treatment and 2.6 times more after 28 days of treatment $(p<0.005$, unpaired t-test) (Table 2).

\subsection{AP(Ca0x)-Index $x_{\text {Mouse }}$ Was Decreased in ARKO Mice}

The AP(CaOx)-index ${ }_{\text {MOUSE }}$ index was calculated to evaluate the risk of in vivo crystallization of calcium oxalate in urine. $\mathrm{AR}^{\mathrm{L}+/ \mathrm{Y}}$ and $\mathrm{AR}^{+/ \mathrm{Y}}$-ORX-DHT exhibited significantly increased values of the $\mathrm{AP}(\mathrm{CaOx})$-index $\mathrm{x}_{\mathrm{MOUSE}}$ index compared with $\mathrm{AR}^{\mathrm{L}-/ \mathrm{Y}}$ and $\mathrm{AR}^{\mathrm{L}-/ \mathrm{Y}}$-ORX-DHT, respectively $(p<0.05$, unpaired t-test) (Table 1$)$. These results suggest that ARKO mice have less risk of crystallization of calcium oxalate by EG loading.

\subsection{GO mRNA Levels Were Decreased in ARKO Mice}

GO and AGT mRNA levels were assessed in livers by Northern blot hybridization. As shown in Figure 2, GO mRNA expression increased significantly in $\mathrm{AR}^{\mathrm{L}+/ \mathrm{Y}}$-ORX-DHT mice compared with $\mathrm{AR}^{\mathrm{L}-/ \mathrm{Y}}$-ORX-DHT mice $(p$ $<0.05$, unpaired t-test). However, the expression of AGT was comparable between $\mathrm{AR}^{\mathrm{L}+/ \mathrm{Y}}$-ORX-DHT mice and $\mathrm{AR}^{\mathrm{L}-/ \mathrm{Y}}$-ORX-DHT mice.

\subsection{Calcium Deposits}

We could not observe any crystals in the kidneys in both groups. We then assessed calcium deposits in the kidneys. Although we expected to observe greater amounts of calcium deposits in floxed AR mice than in ARKO mice, the difference was not significant (Figure 3).

Table 2. Urinary Oxalate Excretion $\left(10^{-6} \mathrm{~mol} / 24 \mathrm{hour} / \mathrm{kg}\right)$ before and after EG treatment.

\begin{tabular}{|c|c|c|c|c|c|c|}
\hline & $\begin{array}{l}\mathrm{AR}^{+/ \mathrm{Y}} \\
\text { intact }\end{array}$ & $\begin{array}{l}\mathrm{AR}^{\mathrm{L}-/ \mathrm{Y}} \\
\text { intact }\end{array}$ & $\begin{array}{c}p \text { value } \\
\text { (unpaired t-test) }\end{array}$ & $\begin{array}{c}\mathrm{AR}^{+/ Y} \\
\mathrm{ORX}+\mathrm{DHT}\end{array}$ & $\begin{array}{c}\mathrm{AR}^{\mathrm{L}-/ \mathrm{Y}} \\
\mathrm{ORX}+\mathrm{DHT}\end{array}$ & $\begin{array}{c}p \text { value } \\
\text { (unpaired t-test) }\end{array}$ \\
\hline Before EG treatment & $31.4 \pm 9.8$ & $9.8 \pm 1.4$ & 0.094 & $17.4 \pm 4.2$ & $10.7 \pm 2.6$ & 0.209 \\
\hline $14^{\text {th }}$ day after EG treatment & $78.7 \pm 11.8$ & $34.7 \pm 6.1$ & 0.016 & $83.4 \pm 11.3$ & $21.5 \pm 4.9$ & 0.003 \\
\hline $28^{\text {th }}$ day after EG treatment & $96.3 \pm 15.2$ & $47.2 \pm 7.1$ & 0.028 & $71.4 \pm 8.1$ & $26.9 \pm 4.4$ & 0.003 \\
\hline
\end{tabular}

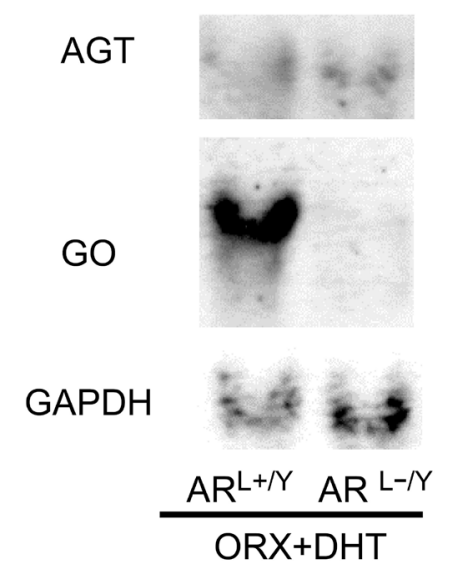

(a)
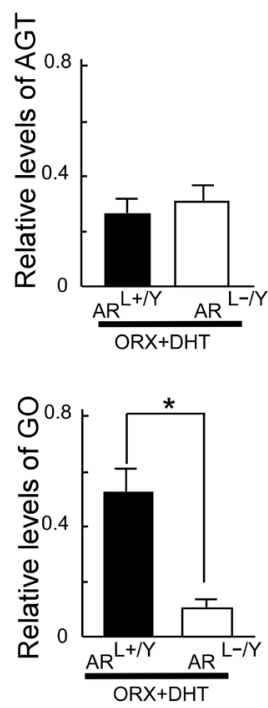

(b)

Figure 2. (a) Northern blotting of RNA from livers of the $\mathrm{AR}^{\mathrm{L}+/ \mathrm{Y}}-\mathrm{ORX}-\mathrm{DHT}$ and $\mathrm{AR}^{\mathrm{L}-/ \mathrm{Y}}-\mathrm{ORX}$-DHT mice after ethylene glycol treatment. (b) Levels of AGT and GO relative to GAPDH in livers from the $A R^{\mathrm{L}+/ \mathrm{Y}}-\mathrm{ORX}-\mathrm{DHT}$ and $\mathrm{AR}^{\mathrm{L}-\mathrm{Y}}$-ORX-DHT mice, quantified from (a). There was no significant difference of AGT expression between $\mathrm{AR}^{\mathrm{L}+/ \mathrm{Y}}-\mathrm{ORX}-\mathrm{DHT}$ and $\mathrm{AR}^{\mathrm{L}-/ \mathrm{Y}}$-ORX-DHT mice. GO expression level was significantly higher in $\mathrm{AR}^{\mathrm{L}+/ \mathrm{Y}}$-ORX-DHT mice compared to $\mathrm{AR}^{\mathrm{L}-\mathrm{Y}}$-ORX-DHT mice $(*, p<0.05)$. 


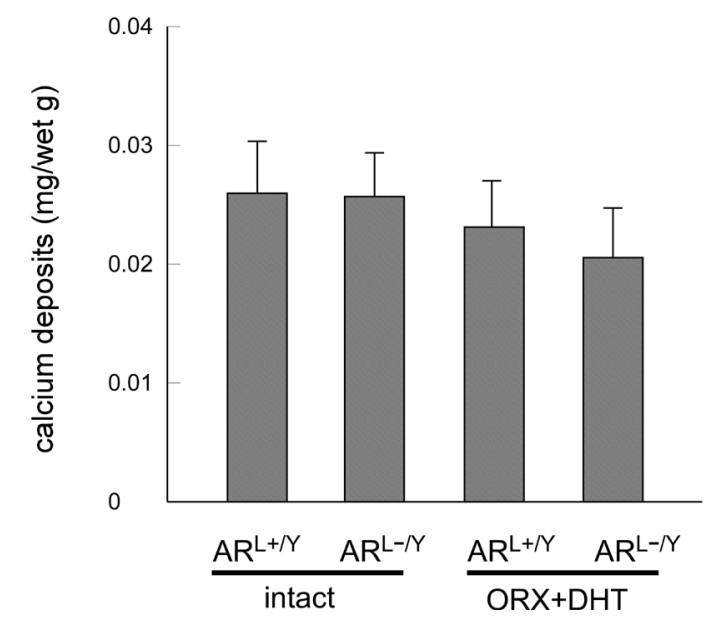

Figure 3. There was no significant difference between the levels of calcium deposits in kidneys after 28 days of EG treatment.

\section{Discussion}

In this study, we measured levels of urinary oxalate in the $\mathrm{AR}^{\mathrm{L}+/ \mathrm{Y}}$ and $\mathrm{AR}^{\mathrm{L}-\mathrm{Y}}$ mice fed normal diet and water, and found that urinary oxalate excretion was higher in the $\mathrm{AR}^{\mathrm{L}+/ \mathrm{Y}}$ mice compared with that in $\mathrm{AR}^{\mathrm{L}-\mathrm{Y}}$ mice, and treatment with EG exacerbated this difference. As the previous studies demonstrated [35] [36], the testes of the $\mathrm{AR}^{\mathrm{L}-/ Y}$ mice were atrophic, and their serum testosterone levels were significantly lower than serum testosterone levels in the $\mathrm{AR}^{+/ Y}$ mice. To equalize the serum androgen levels between the $\mathrm{AR}^{\mathrm{L}+\mathrm{Y}}$ and $A R^{\mathrm{L}-/ \mathrm{Y}}$, the $\mathrm{AR}^{\mathrm{L}+\mathrm{Y}}$ mice were ochiectomised, whereas the $\mathrm{AR}^{\mathrm{L}-/ Y}$ mice were given sham operation because the testes of $\mathrm{AR}^{\mathrm{L}-/ \mathrm{Y}}$ mice were too atrophic to detect, and DHT pellets were then implanted. Even under the same DHT levels, urinary oxalate excretion was significantly higher in $\mathrm{AR}^{+/ \mathrm{Y}}-\mathrm{ORX}$-DHT than in $\mathrm{AR}^{\mathrm{L}-\mathrm{Y}}-\mathrm{ORX}$-DHT mice after EG loading. This suggests that AR may play an important role in oxalate metabolism.

GOmRNA expression was increased significantly in the floxed AR mice compared to ARKO mice. These results suggest that DHT-activated GO may contribute to oxalate production and increased urinary oxalate excretion via AR signaling.

Liang et al. reported that by using the cre-loxP system to selectively knock out AR in glyoxylate-induced calcium oxalate (CaOx) crystal mouse models, they found that the mice lacking hepatic AR had less oxalate biosynthesis, which might lead to lower $\mathrm{CaOx}$ crystal formation, and also demonstrated that the mice lacking kidney proximal or distal epithelial AR also had lower $\mathrm{CaOx}$ crystal formation. They detected an AR biding site on the androgen response element (ARE) in the -626 to -611 bp of the 5' promoter region of GO and performed promoter assay. They found that AR could induce GO expression at the transcriptional level [37].

There are several other studies which indicate the function of stone-related protein using knockout mice, in which they reported that the administration of $1 \%$ ethylene glycol in free drinking or plus vitamin $\mathrm{D}_{3}$ could induce stone formation in knockout mice kidney, but not in wild-type mice [38] [39]. Okada et al. demonstrated that intraperitoneal injection of glyoxylate could induce kidney stone formation in wild-type mice [40]. In our study, we decided that intraperitoneal injection of glyoxylate may be too traumatic for the mice. Therefore, we chose administration of EG by drinking. Although the $\mathrm{AR}^{\mathrm{L}+/ \mathrm{Y}}$ and $\mathrm{AR}^{\mathrm{L}+/ \mathrm{Y}}-\mathrm{ORX}-\mathrm{DHT}$ mice exhibited increased urinary oxalate excretion by EG loading, the formation of kidney stones was not detected in these mice. Animal experiments to study the risk of in vivo crystallization of calcium oxalate in urine should be undertaken with the knowledge of iron-activity products. Recently Tiselius et al. described a simplified calculation to determine the

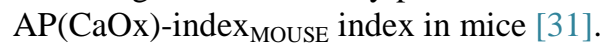

$\mathrm{AP}(\mathrm{CaOx})$-index MOUSE index of the $\mathrm{AR}^{\mathrm{L}+/ \mathrm{Y}}$ and $\mathrm{AR}^{\mathrm{L}+/ \mathrm{Y}}$-ORX-DHT mice treated with EG were significantly increased than that of the $\mathrm{AR}^{\mathrm{L}-/ \mathrm{Y}}$ and $\mathrm{AR}^{\mathrm{L}-/ \mathrm{Y}}$-ORX-DHT mice respectively. This finding suggests that ARKO mice are at less risk for the formation of $\mathrm{CaOx}$ urolithiasis than control mice.

The present study demonstrated that urinary calcium excretion did not differ between control and ARKO mice. However, gender difference in the renal handling of calcium has been previously reported. Male mice had higher urinary calcium excretion than female mice [41] [42], and their renal calcium transporters were expressed at 
lower levels. In addition, androgen-deficient mice after orchiectomy also showed lower urinary calcium excretion than sham-operated male mice, but hypocalciuria was normalized by testosterone replacement therapy [43]. Interestingly, androgen deficiency increased the mRNA and protein expression of the renal luminal transient receptor potential vanilloid-subtype 5 (TRPV5) and intracellular calbindin-D28k transporters, which were then suppressed by testosterone treatment. However, in the present study urinary calcium excretion did not differ between the $\mathrm{AR}^{\mathrm{L}+/ \mathrm{Y}}$ and $\mathrm{AR}^{\mathrm{L}-/ \mathrm{Y}}$, also $\mathrm{AR}^{\mathrm{L}+/}$-ORX-DHT and $\mathrm{AR}^{\mathrm{L}-/ \mathrm{Y}}-\mathrm{ORX}-\mathrm{DHT}$ mice. No previous studies using ARKO mice to evaluate urinary calcium excretion have been reported. We previously used ARKO mice to demonstrate the suppressive function of the AR, which may accelerate calcium release from bone and potentially increase urinary calcium excretion [35]. Furthermore, it is unclear whether activated AR directly or indirectly decreases the expression of TRPV5 in mouse kidneys, because DHT did not modulate TRPV5 promoter activity in a luciferase assay [43]. An experimental study of renal calcium handling in ARKO mice would therefore be intriguing.

The exact mechanisms by which sex hormones have influence on the formation of renal stones are still unclear. Experimental studies using AR knockout mice may contribute to the elucidation of mechanisms of sex difference in morbidity of urolithiasis.

\section{References}

[1] Robertson, W.G., Peacock, M., Heyburn, P.J. and Hanes, F.A. (1980) Epidemiological Risk Factors in Calcium Stone Disease. Scandinavian Journal of Urology and Nephrology. Supplementum, 53, 15-30.

[2] Soucie, J.M., Thun, M.J., Coates, R.J., McClellan, W. and Austin, H. (1994) Demographic and Geographic Variability of Kidney Stones in the United States. Kidney International, 46, 893-899. http://dx.doi.org/10.1038/ki.1994.347

[3] Parks, J.H. and Coe, F.L. (1986) A Urinary Calcium-Citrate Index for the Evaluation of Nephrolithiasis. Kidney International, 30, 85-90. http://dx.doi.org/10.1038/ki.1986.155

[4] Curhan, G.C., Willett, W.C., Speizer, F.E. and Stampfer, M.J. (2001) Twenty-Four-Hour Urine Chemistries and the Risk of Kidney Stones among Women and Men. Kidney International, 59, 2290-2298. http://dx.doi.org/10.1046/j.1523-1755.2001.00746.x

[5] Robertson, W.G. and Peacock, M. (1980) The Cause of Idiopathic Calcium Stone Disease: Hypercalciuria or Hyperoxaluria? Nephron, 26, 105-110. http://dx.doi.org/10.1159/000181963

[6] Robertson, W.G., Peacock, M., Heyburn, P.J., Marshall, D.H. and Clark, P.B. (1978) Risk Factors in Calcium Stone Disease of the Urinary Tract. British Journal of Urology, 50, 449-454. http://dx.doi.org/10.1111/j.1464-410X.1978.tb06189.x

[7] Holmes, R.P., Goodman, H.O. and Assimos, D.G. (2001) Contribution of Dietary Oxalate to Urinary Oxalate Excretion. Kidney International, 59, 270-276. http://dx.doi.org/10.1046/j.1523-1755.2001.00488.x

[8] Siener, R., Bade, D.J., Hesse, A. and Hoppe, B. (2013) Dietary Hyperoxaluria Is Not Reduced by Treatment with Lactic Acid Bacteria. Journal of Translational Medicine, 11, 306. http://dx.doi.org/10.1186/1479-5876-11-306

[9] Ushijima, Y. (1973) Identity of Aliphatic L- $\alpha$-Hydroxyacid Oxidase and Glycolate Oxidase from Rat Livers. Archives of Biochemistry and Biophysics, 155, 361-367. http://dx.doi.org/10.1016/0003-9861(73)90125-2

[10] Warren, W.A. (1970) Catalysis of Both Oxidation and Reduction of Glyoxylate by Pig Heart Lactate Dehydrogenase Isozyme 1. The Journal of Biological Chemistry, 245, 1675-1681.

[11] Poore, R.E., Hurst, C.H., Assimos, D.G. and Holmes, R.P. (1997) Pathways of Hepatic Oxalate Synthesis and Their Regulation. American Journal of Physiology, 272, C289-C294.

[12] Bais, R., Rofe, A.M. and Conyers, R.A. (1991) Investigations into the Effect of Glyoxylate Decarboxylation and Transamination on Oxalate Formation in the Rat. Nephron, 57, 460-469. http://dx.doi.org/10.1159/000186350

[13] Lee, Y.H., Huang, W.C., Chiang, H., Chen, M.T., Huang, J.K. and Chang, L.S. (1992) Determinant Role of Testosterone in the Pathogenesis of Urolithiasis in Rats. The Journal of Urology, 147, 1134-1138.

[14] Lee, Y.H., Huang, W.C., Huang, J.K. and Chang, L.S. (1996) Testosterone Enhances Whereas Estrogen Inhibits Calcium Oxalate Stone Formation in Ethylene Glycol Treated Rats. The Journal of Urology, 156, 502-505. http://dx.doi.org/10.1016/S0022-5347(01)65914-7

[15] Yoshihara, H., Yamaguchi, S. and Yachiku, S. (1999) Effect of Sex Hormones on Oxalate-Synthesizing Enzymes in Male and Female Rat Livers. The Journal of Urology, 161, 668-673. http://dx.doi.org/10.1016/S0022-5347(01)61992-X

[16] Iguchi, M., Takamura, C., Umekawa, T., Kurita, T. and Kohri, K. (1999) Inhibitory Effects of Female Sex Hormones on Urinary Stone Formation in Rats. Kidney International, 56, 479-485. 
http://dx.doi.org/10.1046/j.1523-1755.1999.00586.x

[17] Fan, J., Chandhoke, P.S. and Grampsas, S.A. (1999) Role of Sex Hormones in Experimental Calcium Oxalate Nephrolithiasis. Journal of the American Society of Nephrology, 10, S376-S380.

[18] Yagisawa, T., Ito, F., Osaka, Y., Amano, H., Kobayashi, C. and Toma, H. (2001) The Influence of Sex Hormones on Renal Osteopontin Expression and Urinary Constituents in Experimental Urolithiasis. The Journal of Urology, 166, 1078-1082. http://dx.doi.org/10.1016/S0022-5347(05)65925-3

[19] Yoshioka, I., Tsujihata, M., Momohara, C., Akanae, W., Nonomura, N. and Okuyama, A. (2010) Effect of Sex Hormones on Crystal Formation in a Stone-Forming Rat Model. Urology, 75, 907-913. http://dx.doi.org/10.1016/j.urology.2009.09.094

[20] Li, J.Y., Zhou, T., Gao, X., Xu, C., Sun, Y., Peng, Y., et al. (2010) Testosterone and Androgen Receptor in Human Nephrolithiasis. The Journal of Urology, 184, 2360-2363. http://dx.doi.org/10.1016/j.juro.2010.08.009

[21] Matsumoto, T., Sakari, M., Okada, M., Yokoyama, A., Takahashi, S., Kouzmenko, A. and Kato, S. (2013) The Androgen Receptor in Health and Disease. Annual Review of Physiology, 75, 201-224. http://dx.doi.org/10.1146/annurev-physiol-030212-183656

[22] Dunn, J.F., Nisula, B.C. and Rodbard, D. (1981) Transport of Steroid Hormones: Binding of 21 Endogenous Steroids to Both Testosterone-Binding Globulin and Corticosteroid-Binding Globulin in Human Plasma. The Journal of Clinical Endocrinology \& Metabolism, 53, 58-68. http://dx.doi.org/10.1210/jcem-53-1-58

[23] Sato, T., Matsumoto, T., Yamada, T., Watanabe, T., Kawano, H. and Kato, S. (2003) Late Onset of Obesity in Male Androgen Receptor-Deficient (AR KO) Mice. Biochemical and Biophysical Research Communications, 300, 167-171. http://dx.doi.org/10.1016/S0006-291X(02)02774-2

[24] Li, M., Indra, A.K., Warot, X., Brocard, J., Messaddeq, N., Kato, S., et al. (2000) Skin Abnormalities Generated by Temporally Controlled RXR $\alpha$ Mutations in Mouse Epidermis. Nature, 407, 633-636. http://dx.doi.org/10.1038/35036595

[25] Sekine, K., Ohuchi, H., Fujiwara, M., Yamasaki, M., Yoshizawa, T., Sato, T., et al. (1999) Fgf10 Is Essential for Limb and Lung Formation. Nature Genetics, 21, 138-141. http://dx.doi.org/10.1038/5096

[26] Dupe, V., Davenne, M., Brocard, J., Dolle, P., Mark, M., Dierich, A., et al. (1997) In Vivo Functional Analysis of the Hoxa-1 3’ Retinoic Acid Response Element (3’RARE). Development, 124, 399-410.

[27] Gubbay, J., Collignon, J., Koopman, P., Capel, B., Economou, A., Münsterberg, A., et al. (1990) A Gene Mapping to the Sex-Determining Region of the Mouse Y Chromosome Is a Member of a Novel Family of Embryonically Expressed Genes. Nature, 346, 245-250. http://dx.doi.org/10.1038/346245a0

[28] Sato, T., Matsumoto, T., Kawano, H., Watanabe, T., Uematsu, Y., Sekine, K., et al. (2004) Brain Masculinization Requires Androgen Receptor Function. Proceedings of the National Academy of Sciences of the United States of America, 101, 1673-1678. http://dx.doi.org/10.1073/pnas.0305303101

[29] Kataoka, K., Takada, M., Kato, Y., Iguchi, M., Kohri, K. and Kurita, T. (1990) Determination of Urinary Oxalate by High-Performance Liquid Chromatography Monitoring with an Ultraviolet Detector. Urological Research, 18, 25-28. http://dx.doi.org/10.1007/BF00294577

[30] Sarkar, B.C. and Chauhan, U.P. (1967) A New Method for Determining Micro Quantities of Calcium in Biological Materials. Analytical Biochemistry, 20, 155-166. http://dx.doi.org/10.1016/0003-2697(67)90273-4

[31] Tiselius, H.G., Ferraz, R.R. and Heilberg, I.P. (2012) Simplified Estimates of Ion-Activity Products of Calcium Oxalate and Calcium Phosphate in Mouse Urine. Urological Research, 40, 285-291. http://dx.doi.org/10.1007/s00240-011-0443-1

[32] Christian, G.D. (1969) Medicine, Trace Elements, and Atomic Absorption Spectroscopy. Analytical Chemistry, 41, 24A-40A. http://dx.doi.org/10.1021/ac60270a719

[33] Ambuhl, P., Amemiya, M., Preisig, P.A., Moe, O.W. and Alpern, R.J. (1998) Chronic Hyperosmolality Increases NHE3 Activity in OKP Cells. Journal of Clinical Investigation, 101, 170-177. http://dx.doi.org/10.1172/JCI62

[34] Zisoulis, D.G., Kai, Z.S., Chang, R.K. and Pasquinelli, A.E. (2012) Autoregulation of MicroRNA Biogenesis by Let-7 and Argonaute. Nature, 486, 541-544. http://dx.doi.org/10.1038/nature11134

[35] Kawano, H., Sato, T., Yamada, T., Matsumoto, T., Sekine, K., Watanabe, T., et al. (2003) Suppressive Function of Androgen Receptor in Bone Resorption. Proceedings of the National Academy of Sciences of the United States of America, 100, 9416-9421. http://dx.doi.org/10.1073/pnas.1533500100

[36] De Gendt, K., Atanassova, N., Tan, K.A., de Franca, L.R., Parreira, G.G., McKinnell, C., et al. (2005) Development and Function of the Adult Generation of Leydig Cells in Mice with Sertoli Cell-Selective or Total Ablation of the Androgen Receptor. Endocrinology, 146, 4117-4126. http://dx.doi.org/10.1210/en.2005-0300

[37] Liang, L., Li, L., Tian, J., Lee, S.O., Dang, Q., Huang, C.-K., et al. (2014) Androgen Receptor Enhances Kidney 
Stone-CaOx Crystal Formation via Modulation of Oxalate Biosynthesis \& Oxidative Stress. Molecular Endocrinology, 28, 1291-1303. http://dx.doi.org/10.1210/me.2014-1047

[38] Wesson, J.A., Johnson, R.J., Mazzali, M., Beshensky, A.M., Stietz, S., Giachelli, C., et al. (2003) Osteopontin Is a Critical Inhibitor of Calcium Oxalate Crystal Formation and Retention in Renal Tubules. Journal of the American Society of Nephrology, 14, 139-147. http://dx.doi.org/10.1097/01.ASN.0000040593.93815.9D

[39] Mo, L., Huang, H.Y., Zhu, X.H., Shapiro, E., Hasty, D.L. and Wu, X.-R. (2004) Tamm-Horsfall Protein Is a Critical Renal Defense Factor Protecting against Calcium Oxalate Crystal Formation. Kidney International, 66, 1159-1166. http://dx.doi.org/10.1111/j.1523-1755.2004.00867.x

[40] Okada, A., Nomura, S., Higashibata, Y., Hirose, M., Gao, B., Yoshimura, M., et al. (2007) Successful Formation of Calcium Oxalate Crystal Deposition in Mouse Kidney by Intraabdominal Glyoxylate Injection. Urological Research, 35, 89-99. http://dx.doi.org/10.1007/s00240-007-0082-8

[41] Davis, R.H., Morgan, D.B. and Rivlin, R.S. (1970) The Excretion of Calcium in the Urine and Its Relation to Calcium Intake, Sex and Age. Clinical Science, 39, 1-12.

[42] Morgan, B. and Robertson, W.G. (1974) The Urinary Excretion of Calcium. An Analysis of the Distribution of Values in Relation to Sex, Age and Calcium Deprivation. Clinical Orthopaedics \& Related Research, 101, 254-267.

[43] Hsu, Y.J., Dimke, H., Schoeber, J.P., Hsu, S.C., Lin, S.H., Chu, P., et al. (2010) Testosterone Increases Urinary Calcium Excretion and Inhibits Expression of Renal Calcium Transport Proteins. Kidney International, 77, 601-608. http://dx.doi.org/10.1038/ki.2009.522 